Table 1

Pre and post treatment cephalometric appraisal

\begin{tabular}{|c|c|c|c|}
\hline Cephalometric measurement & Normal & Pre-treatment & Post-treatment \\
\hline Sella-Nasion- A-point $*$ (SNA) & $82+2^{\circ}$ & $83^{\circ}$ & $83^{\circ}$ \\
\hline Sella-Nasion- B-point ${ }^{\#}$ (SNB) & $80+2^{\circ}$ & $78^{\circ}$ & $81^{\circ}$ \\
\hline ANB (SNA- ANB) & $2^{\circ}$ & $5^{\circ}$ & $2^{\circ}$ \\
\hline Wits measurement & $1 \mathrm{~mm}$ & $6 \mathrm{~mm}$ & $2 \mathrm{~mm}$ \\
\hline Cranial length (Basion to Nasion) & $110+4 \mathrm{~mm}$ & $112 \mathrm{~mm}$ & $112 \mathrm{~mm}$ \\
\hline Maxillary length (Basion to A-point) & $97+5 \mathrm{~mm}$ & $95 \mathrm{~mm}$ & $95 \mathrm{~mm}$ \\
\hline Mandibular length (Basion to Pogonion) & $110+6 \mathrm{~mm}$ & $107 \mathrm{~mm}$ & $111 \mathrm{~mm}$ \\
\hline Y Axis (Nasion- Sella- Gnathion) & $66^{\circ}$ & $61^{\circ}$ & $68^{\circ}$ \\
\hline Convexity & $2.3 \mathrm{~mm}$ & $3 \mathrm{~mm}$ & $2 \mathrm{~mm}$ \\
\hline Upper incisor to Nasion- A-point (degree/mm) & $22+2 \% / 4 \mathrm{~mm}$ & $36 \% 9 \mathrm{~mm}$ & $21 \% 4 \mathrm{~mm}$ \\
\hline Lower incisor to Nasion- B-point(degree/mm) & $25+4 \% \mathrm{~mm}$ & $26 \% 4 \mathrm{~mm}$ & $26 \% \mathrm{~mm}$ \\
\hline Upper incisor to Lower incisor & $131^{\circ}$ & $113^{\circ}$ & $133^{\circ}$ \\
\hline Lower incisor to A-point /Pogonion & $1+2 \mathrm{~mm}$ & $0 \mathrm{~mm}$ & $1.5 \mathrm{~mm}$ \\
\hline Nasolabial angle & $95^{\circ}+5^{\circ}$ & $78^{\circ}$ & $94^{\circ}$ \\
\hline
\end{tabular}

* Subspinale, "Supramentale

the maxillary skeleton [8].

TBA therapy achieves about $40 \%$ overjet correction by skeletal and about $60 \%$ by dentoalveolar changes. Correction of buccal segments is by the combination of distal movement of the upper molars and forward migration of lower molars [7].

\section{Conflicts of Interest}

None identified

\section{References}

1. Moorees CFA, Burstone CJ, Christiansen RL, Hixon EH, Wienstien S. Research related to malocclusion: A "State-ofthe-Art" workshop conducted by the Oral-Facial Growth and Development Program, the National Institute of Dental Research. AJO 1971; 59: 1-18.

2. Clark WJ. Twin block functional therapy: applications in dentofacial orthopaedics, $2^{\text {nd }}$ Ed: St Louis: Mosby 2002; 3-4.

3. Clark WJ. The twin block technique: A functional orthopedic appliance system. Am J Orthod Dentofacial Orthop 1988; 93: $1-18$

4. Chadwick SM, Banks PA, Wright JL. The use of myofunctional appliances in the UK: A survey of British ortho-dontists. Dent Update 1998; 25: 302-8.

5. Gill DS, Lee RT. Prospective clinical trial comparing the effects of conventional Twin Block and mini-block appliances: Part 1. Hard tissue changes. Am J Orthod Dentofacial Orthop 2005; 127: 465-72.

6. Šidlauskas A. Clinical effectiveness of the Twin block appliance in the treatment of Class II Division 1 malocclusion. Stomatologija, Baltic Dental and Maxillofacial Journal 2005; 7 : 7-10.

7. Šidlauskas A. The effects of the twin-block appliance treatment on the skeletal and dentoalveolar changes in Class II Division 1 malocclusion. Medicina 2005; 41: 392-400.

8. Antonarakisa GS, Kiliaridisb S. Short-term anteroposterior treatment effects of functional appliances and extraoral traction on class II malocclusion a meta-analysis ; Angle Orthodontist 2007; 77: 907-14.

\title{
ERRATUM
}

Letter To Editor : "Severe Symptomatic Diuretic Induced Hyponatremia” MJAFI April 2010; 66 : 198, para 4 , line 7.

For: He was started with $3 \%$ normal saline at the rate of $30 \mathrm{ml} / \mathrm{min}(0.5 \mathrm{ml} / \mathrm{kg})$.

Read: He was started with $3 \%$ normal saline at the rate of $30 \mathrm{ml} / \mathrm{hour}(0.5 \mathrm{ml} / \mathrm{kg} / \mathrm{hour})$.

The error is regretted. 